\title{
A Measurement Scale of the Attitude towards the Branded Product Sales Promotion
}

\author{
Mouna Damak Turki \\ Laboratoire de recherche en marketing (LRM) \\ Faculté des Sciences Economiques et de Gestion de Sfax, Sfax, Tunisie \\ damak_mouna@yahoo.fr \\ Received date: 6 March 2017; Accepted date: 26 May 2017; Published date: 11 October 2017 \\ Academic Editor: Sawssen Garbouj Chaouachi \\ Copyright (C) 2017. Mouna Damak Turki. Distributed under Creative Commons CC-BY 4.0

\begin{abstract}
The notion of attitude has widely attracted marketing researchers. This study seeks to extend the resource-based view to the context of the consumers' behavior. It is intended to develop a measurement scale of attitude towards the sales promotion of branded products, and to verify its psychometric qualities. The present work encompasses the results of an approach inspired of the Churchill paradigm of developing a measurement scale administered to a sample set of 400 consumers. The results obtained showed that the optimal scale is two-dimensional and profits from acceptable psychometric qualities.
\end{abstract}

Keywords: Attitude, sales promotion, measurement scale

\section{Introduction}

Up until several years ago, promotions were considered less effective when given the choice of traditional advertising or sales promotions (Mendez et al., 2015). Today, sales promotion has become the most predominant strategy in the marketing of consumer packed goods, accounting for almost a quarter of the marketing budget of consumer product companies (Raghubir et al., 2004).

Additionally, Research in marketing has markedly progressed during the last decade. Indeed, more investigation has specifically addressed the consumer behavior and investigated the mechanisms that might explain their responses to the marketing campaigns (Froloff, 1994, Laroche et al., 2003, Zarrouk, 2010, Damak Turki, 2013).

In this regard, a consumer-oriented research trend has explored the psychological phenomena that could explain the attractiveness of sales promotion (Boland et al., 2012, Laroche et al., 2003, Allender and Richards, 2012 Buil, 2013).

However, this theoretical endeavor has seldom included proposals of a measuring instrument likely to account for the various behaviors, notably in a special context characterized by increased competition, a

Cite this Article as: Mouna Damak Turki (2017), " A Measurement Scale of the Attitude towards the Branded Product Sales Promotion ", Journal of Marketing Research and Case Studies, Vol. 2017 (2017), 
chameleon consumer that looks for opportunities (Dubois and Jolibert, 2005, Rettie and Brewer, 2000), an excessive number of advertising communications that makes the consumer more requiring (Hutchins, on 1997; Neslin, on 2002, Dubois and Jolibert, 2005) and the necessity of new forms of distribution (Ailawadi, on 2001; Neslin, on 2002).

This work thus tries to bridge this gap by providing the researchers and managers with a new tool to measure the attitude towards sales promotion, particularly for accessible branded products. This research also aims at checking the validity of the concept and its characteristics.

This research attempts to enrich the marketing literature by presenting a measurement instrument of the attitude toward the sale of branded products that, up to our knowledge, is not yet thoroughly established given the fact that all the developed scales have addressed mass products that differ largely from the branded products generating particular consumer attitudes and behaviors. In fact, the findings of Chandon et al. (2000), Liao (2006), and Palazón-Vidal and DelgadoBalleter (2005) confirm that not all sales promotional tools are similarly effective for all product categories. In addition, DelVecchio et al.'s (2006) findings either concluded that depending upon characteristics of the sales promotions and the promoted product, promotions could increase or decrease preference for a brand.

In this work, we initially investigate the notion of attitude and its relation with sales promotion. Then, we present the established methodology for developing a measurement scale based on the Churchill paradigm (1979). Eventually, we interpret the results of the tests carried out on the suggested scale and we address managerial implications, limitations and directions for future research.

\section{Conceptual framework}

In marketing, attitude is defined as " $a$ learned predisposition to behave in a constantly favorable or unfavorable way with respect to a given object or situation" (Pellemans, 1998).

Attitude was also presented by Michelik (2008) as "an intermediate variable that prepares the individual for action in a certain manner toward a given object".

Attitude thus represents a filter that organizes our recognition of things and adjusts our behavior. Indeed, it is commonly admitted that there is a positive cause effect relationship between attitude and behavior. However, this relationship is neither perfect nor automatic. Moreover, a favorable attitude towards a brand is not necessarily related to the purchase, because the consumer can develop a favorable attitude towards a brand without having ever purchased it (Lewi and Lacoeuilhe, 2007).

Attitude is thus a mental predisposition that precedes a behavior and has several characteristics. Indeed, it is neither innate nor directly observable. It is the consequence of a learning constructed by means of information and personal experience. Finally, it is worth noting that attitude is positively or negatively adjusted, and that its intensity varies according to the degree of involvement towards the object or the situation.

For example, at sales promotion, the consumers who are strongly involved adopt a more favorable attitude towards sales promotion and vice versa (Pellemans, 1998).

Several theoretical approaches have developed the notion of attitude namely the multidimensional perspective, the unidimensional perspective, the balance theory of Heider (1946) and the behaviorist theory of Fishbein (1975).

\section{Attitude toward Branded Products Sales Promotion}

The concept of attitude toward sales promotion has drawn the attention of several researchers.

In this context, Mittal (1994) argued that the attitude toward the purchase on sale 
constitutes the whole of positive or negative feelings that the consumer expresses towards sales promotion. Indeed, the variety of attitude is better explained by the feeling of satisfaction towards non-monetary promotion such as the use of coupons rather than by the set of costs according to time. Alvárez et al (2005) find also that consumers' attitude and purchase decision is widely related to the existence of monetary and nonmonetary promotions. According to this assumption, building attitudes seems strongly related to the feelings and emotions of the consumer toward sales promotion.

Nevertheless, a feeling is never evoked without having prior information in advance, i.e. beliefs concerning the object in question so the cognitive aspect explains also the attitude of the consumer towards purchasing at sales promotion (Damak, 2016, Froloff, 2000; Hachicha, 2007).

Moreover, most early research studies on sales promotions focused on the effects of sales promotions on sales and profits, the effects of promotions on consumer attitude and purchase behavior during the promotional period, and the effects of a promotional purchase on subsequent choice behavior (Mendez et al., 2015).

Furthermore, the relation between the sales promotion and the brand choice is also well developed by Gedenk and Neslin (1999) who found that the promotional status of the previous purchase could differentially influence brand choice, through purchase event feedback. Moreover, after buying a brand on promotion if the consumer is asked: Did you buy this brand because you like the brand, or because of the promotion? The answer is generally because of "the promotion", (Gedenk \& Neslin, 1999, p. 435)

On the other hand, Bridges et al., (2006) studied how various promotions mark consumer response to subsequent marketing mix activities. They refer to previous theoretical and empirical research studies that support the effects of prior brand purchases on consumer attitude and response to promotions.

They identified two streams: usage dominance and promotion enhancement. The usage dominance concept suggests that, after purchase and use of a brand, consumers become less responsive to promotional activities for that brand because their direct experience dominates external information. What this implies is that consumers who are more focused on their personal experience are less responsive to marketing mix activities for the most recently purchased brand and, consequently, are more likely to repurchase the brand after a promotion has ended (Bridges et al., 2006).

On the other hand, promotion enhancement indicates that promotions reduce subsequent brand loyalty due to the increased sensitivity to marketing mix activities for all brands in the category. In other words, promotion enhancement implies a reduced likelihood to buy previously purchased brands, simultaneously with an increase in the impact of promotional activities for all brands in the category (Bridges et al., 2006).

Thus, consumer behavior toward sales promotion of branded products is difficult to comprehend and the attitude toward promotions looks as a psychological concept whose measurement shall be a delicate issue especially in the context of branded products whose target is as specific as the studied products.

Our research objective is also motivating especially for managers because of the positive association between an individual's attitude toward an object, a brand, or situation such as marketing campaign and their subsequent behavior (Ajzen and Fishbein, 1980; Bagozzi, et al., 1989). Thus, if a consumer has a positive attitude toward a brand, it is more likely that he purchases that brand if it is on sales promotion. 


\section{The Measurement of Attitude}

Various methodological approaches have been suggested to determine consumer attitudes. However, the adoption of a measurement scale remains the most effective means to measure attitude. Several types of scales can be used such as the Guttman scale, the differential semantic scale and the Likert scale (Pellemans, 1998).

A survey of the marketing literature enabled us to determine the measurement scales developed within the framework of sales promotion. Indeed, we determined five measurement scales: Kalika (1982) which contains 5 items, Guilbert (1981) which comprises 4 items, Shimp and Kavas (1984) which is a differential scale containing 5 items, Volle (1996) which contains 2 items and Froloff Brouche (2000) with 3 items.

Nevertheless, no scale considered the three dimensions of attitude altogether. Most scales accounted whether for one or two dimensions. Moreover, none measured the attitude toward the sale of branded products. The latter differ largely from mass products that are accessible to everyone such as (detergents: shampoo or soap, conserve, milk and yogurts....).

This work studies the attitude toward sales promotion of branded products by jointly taking account of three dimensions (emotional, cognitive and conative). It thus lies within the scope of a multidimensional approach to attitude.

\section{Research Methodology}

The purpose of this research is to develop a psychometrically robust measure of the attitude toward the branded product sales promotion. We opted for some accessible branded products such as perfumes, watches, branded clothes, bags and shoes (Mickel Kors, Burberry, Dior, Louis Vuiton ...).

This choice was based on a qualitative research by focus groups and a lexical analysis was led to calculate the repetition frequencies.

To reach our objective, four separate studies were undertaken to generate and refine scale items (Study 1), determine and then confirm the underlying factor structure of brand authenticity (Studies 2 and 3), and finally to test for convergent, discriminant and predictive validity of the scale (Study 4).

Our research sample is non probabilistic and composed of 400 consumers selected according to the subjective judgment of the researcher. Convenience sampling is a nonprobability sampling technique where subjects are selected because of their convenient accessibility and proximity.

\section{Study 1: Item Generation and Refinement}

Churchill's (1979) scale development paradigm was adopted, using a deductive approach for the generation of scale items (Schwab, 1980).

Drawing on the extant literature, an initial list of 12 items/statements was generated reflecting three dimensions of the attitude toward sales promotion, which includes the emotional, conative and cognitive components.

Next, we refer to works for a qualitative study to build a coherent scale for attitudes toward the sales promotion of branded products, this process resulted in further 4 items being eliminated. The final sample of scale items consisted of 8 items.

Items were placed on a five-point Likert scale, anchored by 1 'strongly disagree' and 'strongly agree and pilot tested among 40 consumers.

The scale parameters of the first version of the questionnaire were based on a qualitative research and on the literature in the domain and looked as follows: 


\begin{tabular}{|c|c|}
\hline & Items \\
\hline 1 & I move to benefit from a possible sale \\
\hline 2 & I like to buy branded products on sale \\
\hline 3 & I feel pleased when I buy branded products on sale \\
\hline 4 & I appreciate the fact of buying branded products on sale \\
\hline 5 & $\begin{array}{l}\text { Sales promotion on the branded products makes me buy articles that I would not have } \\
\text { bought differently and which I do not need }\end{array}$ \\
\hline 6 & $\begin{array}{l}\text { Sales promotion on the branded products make it possible to immediately buy articles } \\
\text { which I would have bought later }\end{array}$ \\
\hline 7 & Sales promotion on the branded products delays the purchases \\
\hline 8 & $\begin{array}{l}\text { Sales promotion on branded products makes it possible to buy articles which we could not } \\
\text { afford to buy }\end{array}$ \\
\hline
\end{tabular}

The obtained scale includes the conative (item 1), emotional (items 2, 3 and 4) and cognitive (items 5, 6, 7 and 8) dimensions.

In the present work, it is practically difficult to find a preset survey basis for objects. Thus, we opted for an empirical method. The suitability sampling method was selected for reasons of practicability. Moreover, in management research, the researcher-selected samples are more frequently used than probabilistic samples (Royer and Zarlowski, 2000; city by Thiéthart and Coll, 2002). In our case, the sample set included 200 consumers and the data-collection was carried out by means of a self-administered questionnaire.

\section{Study 2: Item Reduction and Reliability Testing}

The Churchill methodology (1979) lies within the scope of the measurement theory that aims to test the quality of the measurement instruments such as the attitude scales. This methodology is based on specifying the construct domain, generating a sample of items, collecting data, purifying measurements, collecting data, estimating faithfulness, estimating validity and developing standards.

So, The second stage of the research involved further purification of scale items and an assessment of the internal reliability of the 8 items. Each of the 8 scale items was placed on a five-point scale anchored by 1 'strongly disagree' and 5 'strongly agree'.

Data were collected in a first time from 200 consumers with an average age of 32 years, with a relatively even split between male (43\%) and female (57\%) respondents.

This scale was then slightly modified and adapted to the context according to an initiation test on 40 people to further adjust it to our research objectives. Table 1 illustrates the results of purification obtained. 
Table 1: Measurement scale of attitudes toward branded products sales promotion adapted to the research context

\begin{tabular}{|l|c|}
\hline \multicolumn{1}{|c|}{ Labels } & Notations \\
\hline I move for a possible sale & AT 1 \\
\hline I like to buy branded products on sale & AT2 \\
\hline I feel pleased to buy branded products on sale & AT3 \\
\hline I appreciate the fact of buying branded products on sale & AT4 \\
\hline Sales promotion of the branded products makes it possible to advance purchases scheduled for later & AT5 \\
\hline on. & AT6 \\
\hline $\begin{array}{l}\text { Sales promotion of the branded products sometimes delays the purchases } \\
\text { afford to buy }\end{array}$ & AT7 \\
\hline
\end{tabular}

The purification of the scale of attitude towards the branded product sales promotion led to the following results. First, the correlation matrix determinant was about 0.041- thus different from 0 . Moreover, the Kaiser Meyer Olkin sampling precision measurement was 0.805 - thus higher than 0.5, which allowed us to factorize measurements.

The factor analyses with Varimax rotation also proved that the attitude scale is twodimensional. Indeed, two factors having eigenvalues higher than 1 emerged. These two factors made it possible to recover $75.775 \%$ of information. The first factor included 3 items (AT 1, AT 2, AT 3) and the second factor comprised 3 items (AT 5, AT 6, AT 7) as well. Item AT4 was omitted by the extraction.

The content analysis of the items that made up the two factors allowed us to obtain F1 and F2.

F1: attraction towards the branded product sales promotion

F2: unforeseen purchase at a sales promotion

\section{Table 2: Result of extraction (Squared Multiple Correlations)}

\begin{tabular}{|l|r|}
\hline Items & Extraction \\
\hline AT7 &, 567 \\
AT6 &, 834 \\
\hline AT5 &, 714 \\
AT4 &, 473 \\
\hline AT3 &, 694 \\
\hline AT2 &, 849 \\
\hline AT1 &, 850 \\
\hline
\end{tabular}


Table 3: Result of the Factor Analysis with Varimax Rotation Relative to Attitude Construct

\begin{tabular}{|c|c|c|}
\hline Items & F1 & F2 \\
\hline AT1 & 0.861 & \\
\hline AT2 & 0.833 & \\
\hline AT3 & 0.900 & 0.757 \\
\hline AT5 & & 0.831 \\
\hline AT6 & & 0.756 \\
\hline AT7 & 40.610 & 35.165 \\
\hline Inertia recovered by the two & & \\
\hline
\end{tabular}

Table 4: Study of the Reliability of Attitude Construct toward Branded Product Sales Promotion

\begin{tabular}{|l|c|}
\hline \multicolumn{1}{|c|}{ Items } & $\begin{array}{c}\text { Cronbach's Alpha if Item } \\
\text { Deleted }\end{array}$ \\
\hline I move for a possible sale & 0.834 \\
\hline I like to buy branded products on sale & 0.841 \\
\hline I feel pleased to buy branded products on sale & 0.884 \\
\hline Attraction towards the branded product sales promotion & $\mathbf{0 . 8 9 7}$ \\
\hline Sales promotion of the branded products makes it possible to & 0.693 \\
\hline advance purchases scheduled for later on & 0.521 \\
\hline Sales promotion of branded products sometimes delays purchases & 0.795 \\
\hline $\begin{array}{l}\text { Sales promotion of the branded products makes it possible to buy } \\
\text { articles which we could not afford to buy }\end{array}$ & $\mathbf{0 . 7 5 3}$ \\
\hline Unforeseen purchase at sales promotion & \\
\hline
\end{tabular}

The reliability analysis revealed that the Cronbach Alpha value is acceptable for the two previously selected factors which is within Nunnally's (1978) guidelines for scale development $(n=400)$. Consequently, the concept of attitude becomes twodimensional and includes 5 items. Item AT7 was eliminated in order to improve the Alpha value.
The first factor corresponded to "Attraction towards the branded product sales promotion" with $(\alpha=$ 0.897), the second "Unforeseen purchase at sales promotion" ( $\alpha=0.753)$

The Cronbach alphas for each of the dimensions fall within Nunnally's (1978) 
guidelines and attest to the internal consistency of the scale. These items formed the basis for further structural testing through confirmatory factor analysis in Study 3.

Study 3: confirmatory factor analysis

The results of the exploratory factor analysis showed that the attitude construct toward sale has an acceptable level of reliability. This two-dimensional construct is formed by two factors:

F1: attraction towards the branded product sales promotion

\section{F2: unforeseen purchase at a sale}

In order to evaluate the items and the underlying factor structure, a series of confirmatory factor models were examined using the data gathered from a second sample of consumers $(n=400)$. Using the data obtained from the second sample, structural equation modeling was used to perform a confirmatory factor analysis.

Validity Study of the Scale of the Attitude toward the Branded Products Sales Promotion

We aimed to study the discriminant and convergent validity. The analysis was carried out with the AMOS software (version 20) based on the maximum likelihood method. Nevertheless, this method requires a multi normal distribution of variables of the construct. We study Kurtosis and Skewness values. Indeed, the Kurtosis value is accepted up to 8 in absolute value; whereas the Skewness value should not exceed the threshold of 3 in absolute value (Roussel et al., 2002).

Table 5: Study of the attitude construct normality toward the branded product sales promotion

\begin{tabular}{|l|l|l|l|l|l|l|}
\hline Variable & Min & Max & Skew & c.r. & Kurtosis & c.r. \\
\hline AT6 & 1.000 & 5.000 & .770 & 6.289 & .585 & 2.387 \\
\hline AT5 & 1.000 & 5.000 & .710 & 5.799 & .484 & 1.975 \\
\hline AT3 & 1.000 & 5.000 & 1.110 & 9.065 & .608 & 2.481 \\
\hline AT2 & 1.000 & 5.000 & 1.215 & 9.917 & .746 & 3.047 \\
\hline AT1 & 1.000 & 5.000 & 1.394 & 11.386 & 1.350 & 5.511 \\
\hline
\end{tabular}

According to the table, we notice that the Skewness values are lower than 3 while the Kurtosis values are lower than 8. We conclude that attitude construct has a distribution close to normal. These conditions enable us to carry out the discriminant and convergent validity analysis.

\section{Convergent validity analysis of attitude construct}

We opted for the method of Fornell and Larcker (1981) to study the convergent validity of attitude construct toward sales promotion. The realization of this test requires the calculation of the average variance extracted from the construct. The results are presented in the following table: 
Table 6: Study of the convergent validity of attitude construct toward branded product sales promotion

\begin{tabular}{|c|c|c|c|c|c|c|}
\hline & & & $\begin{array}{c}\text { Estimate } \\
\text { (factor weight) }\end{array}$ & $\begin{array}{c}\text { S.E. } \\
\text { (error variance) }\end{array}$ & $\begin{array}{c}\text { C.R } \\
\text { (test T) }\end{array}$ & AVE \\
\hline AT1 & $<---$ & Attraction & 1.000 & & & AVE $=\mathbf{0 . 7 6 6}$ \\
\hline AT2 & $<---$ & Attraction & 1.023 & .035 & 28.827 & \\
\hline AT3 & $<---$ & Attraction & .909 & .038 & 23.640 & \\
\hline AT5 & $<---$ & Unforeseen & 1.000 & & & AVE $=\mathbf{0 . 7 8 3}$ \\
\hline AT6 & $<---$ & Unforeseen & 1.073 & .068 & 15.813 & \\
\hline
\end{tabular}

According to the table, we note that the T test values associated with the factor weights are higher than 1.96 and that the values of the average variance extracted are higher than 0.5. We conclude that attitude construct toward the sale of branded products has an acceptable level of convergent validity.

\section{Discriminant validity analysis of attitude construct}

According to the approach of Fornell and Larker (1981), checking the discriminant validity requires a comparison between the AVE value and the square of the structural link for each construct (Akrout, 2010). Indeed, the mean variance extracted for each construct should be higher than the square of the structural link.

In the case of the attitude scale, calculating the squared correlation between attraction towards sale and the unforeseen purchase
(0.635) are equal to 0.4 ; which definitely proves this condition. We conclude that attitude construct toward the sales promotion of the branded products has acceptable discriminant validity.

\section{Structure model Test of the attitude toward the branded product sales promotion}

As shown in Table 6, the two factor correlated model provided the best fit of the data. The fit statistics were chi-square = $10.949,4$ degrees of freedom; comparative fit index $(\mathrm{CFI})=.995$, non-normed fit index (TLI) $=.988$, normed fit index $(\mathrm{NFI})=.992$, and the root mean square error of approximation (RMSEA) $=.066$, which are within the guidelines recommended by Kelloway (1998).

The estimate results represented an adjustment level in conformity with the theoretical thresholds recommended by the marketing literature.

Table 7: Confirmatory factor analysis results

\begin{tabular}{|l|l|l|l|l|l|l|l|l|l|l|}
\hline Index & RMR & GFI & AGFI & NFI & TLI & CFI & RMSEA & Chi 2 & Dl & $\chi^{2} /$ dl \\
\hline Value & 0.02 & .989 & .96 & .992 & .988 & .995 & 0.066 & 10.949 & 4 & 2.73 \\
\hline
\end{tabular}




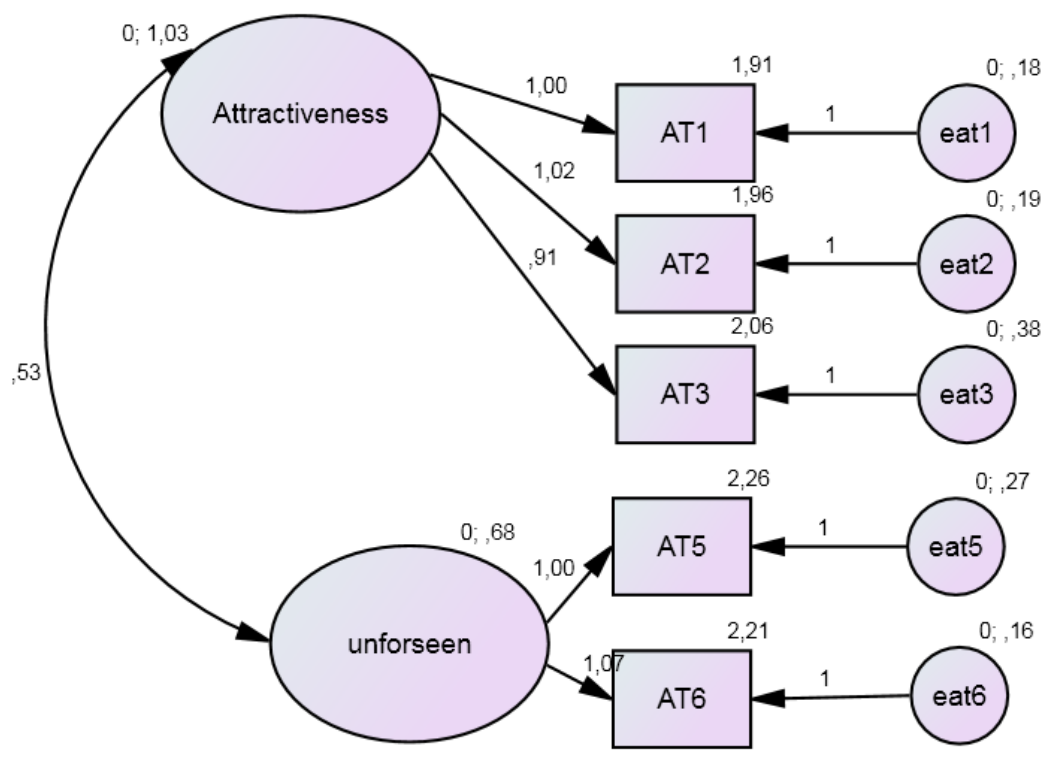

\section{Study 4: assessing construct and predictive validity}

The full process of scale construct culminates in testing its predictive validity by checking whether the relations between measurements of a concept and those of other concepts are in conformity with the predictions from the literature (Evrard et al., 2003).

We thus tested the attitude measurement scale suggested to our samples, which had good internal coherence reliability and satisfactory adjustment qualities along with other factors like sensitivity, motivation and the belief toward sales 
promotion. The obtained results show that these variables are positively related to the attitude toward the branded products sales promotion. The tested model was welladjusted to the data. These results support the nomological validity of the scale of attitude toward the sales promotion.

The fit statistics generated through structural equation modeling, were chisquare $=359.383$ degrees of freedom (126); comparative fit index $(\mathrm{CFI})=.966$, non-normed fit index (TLI) $=.954$, normed fit index $(\mathrm{NFI})=.950$, the root mean square error of approximation (RMSEA) $=.068$, and the level of likelihood (PML) is lower than $1 \%$, which were close to Kelloway's (1998) recommended values.

Overall, the results from Study 4 support the stability of the measurement scale of the attitude toward branded products sales promotion,

Table 8: Adjustment of the structure model of the attitude toward the branded product sales promotion

\begin{tabular}{|l|l|l|l|l|l|l|l|l|l|l|l|}
\hline Index & RMR & GFI & AGFI & NFI & TLI & CFI & RMSEA & Chi 2 & DI & $\chi^{2} /$ dl & Pb (MI) \\
\hline Value & 0.039 & .913 & .870 & .950 & .954 & .966 & 0.068 & 359.383 & 126 & 2.85 & 0.000 \\
\end{tabular}




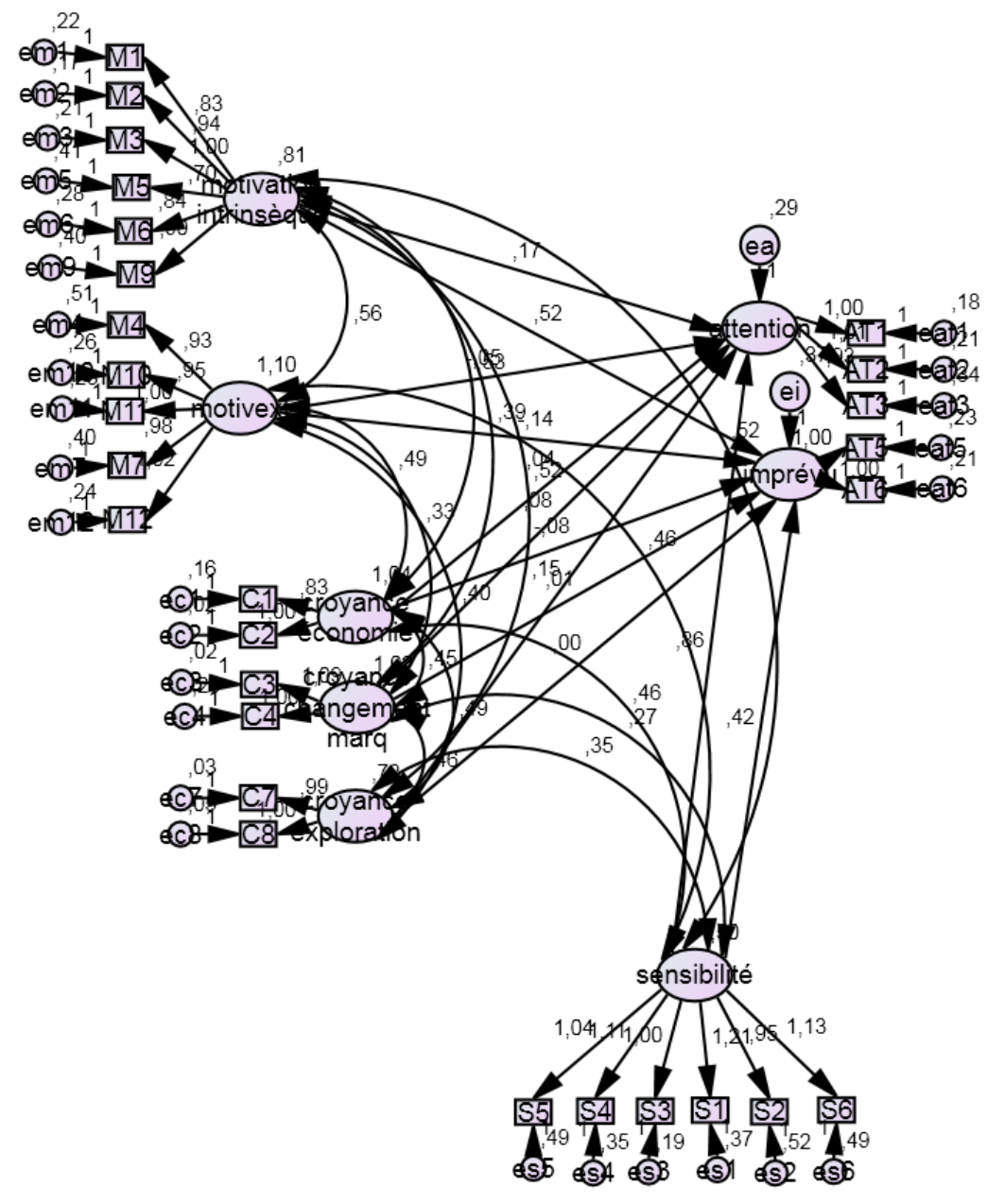

\section{Conclusion}

The study of attitude toward the sales promotion is essential to the research in the field of management, notably for marketing. New issues are being highlighted in order to corroborate the effort of conceptualization and to account for the evolution of this psychological concept difficult to measure.
This study investigates the steps of creating a measurement scale for the attitude toward the branded product sales promotion as well as the obtained results. The developed scale provided very satisfactory psychometric qualities. The exploratory factor analyses were highly reliable. The confirmatory analyses that relied on the method of structural equations also showed a good adjustment with the collected data as well as an acceptable convergent, discriminant and 
nomological validity. Our results corroborate mainly with works which consider that the attitude is a twodimensional concept.

Practically, the suggested measurement tool helps companies that face complex, dubious and turbulent environments to anticipate the attitude of the target consumers in periods of sales promotions of accessible branded products.

This research is not void of limitations, in particular from a methodological point of view. First, although a review of the literature highlighted three factors of the attitude, only two factors emerged in our analysis, namely attraction towards the branded product sales promotion and unforeseen purchase at a sale.

Second, the use of self-administered questionnaires presents the risk of social desirability bias.

Moreover, the study addressed only several branded products of different categories so generalization must thus be made with precaution.

Finally, we have used the classical test of validity for proposed scale and have followed the procedure outline by Fornell and Larcker (1981), measures for each of the constructs in question have been obtained from the same source, which may have an effect on the results produced (Podsakoff and al., 2003).

Through this research, we proposed to apply the scale to new sectors and contexts and encourage research in this field seen that sales promotion has always been unprivileged in marketing and its application has been limited to mass consumption products.

\section{References}

1. Ajzen, I. et Fishbein, M. (1980), Understanding attitudes and predicting social behavior. London: Prentice Hall.

2. Akrout F (2010), La méthode des équations structurelles, 1 ère édition, LRM.
3. Allender WJ et Richards TJ (2012), Brand loyalty and price promotion strategies: an empirical analysis , Journal of Retailing, Vol 88, issue 3, pp 323-343.

Alvarez B A, Vázquez Casielles R (2005), Consumer evaluations of sales promotion: the effect on

4. brand choice, European Journal of Marketing, Vol. 39, issue 1/2, pp.54- 70.

5. Bagozzi, R. P., Baumgartner, J. et Yi, Y. (1989), An investigation into the role of intentions as mediators of the attitude behavior relationship, Journal of Economic Psychology, Vol 10, º1, pp 35-62.

6. Boland WA, Connell PM , Erickson LM (2012), Children's response to sales promotions and their impact on purchase behavior , Journal of Consumer Psychology, Vol 22, issue 2, pp 272-279.

7. Bridges E, Briesch RA, Yim CKB (2006), Effects of prior brand usage and promotion on consumer promotional response, Journal of Retailing, Vol 82,issue 4, pp 295-307.

8. Buil I, De Chernatony L, Martínez E (2013), Examining the role of advertising and sales promotions in brand equity creation, Journal of Business Research, Vol 66, pp 115-122.

9. Chandon, P, Wansink, B, \& Laurent, G (2000), A benefit congruency framework of sales promotion effectiveness, Journal of Marketing, 64, pp 65-81.

10. Churchill G.A (1979), A Paradigm for Developing Better Measure of Marketing Constructs, Journal of Marketing Research, Vol.16, N¹, pp.63-73.

11. Damak Turki. M (2016), "les antécédents de l'attitude à l'égard de la promotion des marques de luxe", Revue des Sciences de Gestion, Direction et Gestion, Vol 4, N 280, pp 75- 83.

12. Damak Turki. M (2013), «Les antécédents psychologiques, psychosociologiques et individuels de l'attitude du consommateur à l'égard de la promotion des ventes: Cas des produits de marque », Thèse de Doctorat en Sciences de 
Gestion, Faculté des sciences économiques et de gestion de Sfax, Tunisie.

13. Del Vecchio, D., Henard, D. H., \& Freling, T. H. (2006), The effect of sales promotion brand preference: A metaanalysis, Journal of Retailing, vol 82, issue 3, pp 203-213.

14. Evrard Y, Pras B et Roux E (1997), Market - Études et recherches en marketing, Nathan, 2ème édition.

15. Fornell C et Larker D.F (1981), Evaluating structural equation models with unobservable variables and measurement error, Journal of Marketing Research, 18, 2, pp 39-50.

16. Froloff Brouche L (2000), Le comportement d'achat en promotion : déterminants et variables modératrices, Thèse de Doctorat ès Sciences de Gestion, ESA Grenoble.

17. Fishbein M et Ajzen I (1975), Belief, attitude, intention, and behavior: An introduction to theory and research Reading, MA: Addison-Wesley.

18. Froloff Brouche L (2000), Le comportement d'achat en promotion : déterminants et variables modératrices, Thèse de Doctorat ès Sciences de Gestion, ESA Grenoble.

19. Froloff L (1992), La sensibilité du consommateur à la promotion des ventes : de la naissance à la maturité, Recherche et Applications en Marketing, 7, 3, pp 69-88.

20. Guilbert F (1981), La stratégie promotionnelle de l'hypermarché et son impact sur le consommateur : le cas des biens durables, Thèse pour le Doctorat de $3^{\text {ème }}$ cycle, IAE Lille.

21. Hachicha F (2007), Les antécédents psychologiques de la sensibilité du consommateur à la promotion des ventes : test et validation d'un modèle, Actes du XXIIIème Congrès International de l'AFM, Aix-les-Bains.
22. Heider F (1946), Attitudes and Cognitive Organization, Journal of Psychology, 21, pp 107-112.

23. Kalika M (1982), Perception et mémorisation des campagnes promotionnelles dans la distribution, Revue Française de Marketing, 90, 3, pp 67-87.

24. Kelloway, E. K. (1998). Using LISREL for structural equation modeling: A researcher's guide. Thousand Oaks, CA: Sage Publications.

25. Laroche M, Pons F, Zgolli N, Cervellon MC, Kim CH (2003), A model of consumer response to two retail sales promotion techniques, Journal of Business Research, 56,7 , pp 513-522.

26. Lewi G et Lacoeuilhe J, (2007), Branding management: La marque, de l'idée à l'action, Pearson Education.

27. Liao, S.L. (2006), The effects of nonmonetary sales promotions on consumer preferences: The contingent role of product category, The Journal of American Academy of Business, Cambridge, Vol 8, issue 2, pp 196-203.

28. Mendez $M$, Bendixen $M$, Abratt $R$, Yurova Y, O'Learyet B (2015), Sales Promotion and Brand Loyalty: Some New Insights , International Journal of Education and Social Science, Vol. 2 No. 1, pp103 117.

29. Michelik F(2008), La relation attitudecomportement: un état des lieux, Éthique et économique, 6,1.

30. Mittal B (1994), An Integrated Framework for Relating Diverse Consumer Characteristics to Supermarket Coupon Redemption, Journal of Marketing Research, Vol 31, pp 533-544.

31. Palazón-Vidal, M., \& DelgadoBallester, E. (2005), Sales promotions effects on consumer-based brand equity, International Journal of Market Research, vol 47, issue 2 , pp 179-204. 
32. Pellemans P (1998), Le marketing qualitatif : perspective psychoscopique, De Boeck Université Paris.

33. Podsakoff, P. M., MacKenzie, S. B., Lee, J. L., \& Podsakoff, N. P. (2003), Common method biases in behavioral research: A critical review of the literature and recommended remedies, Journal of Applied Psychology, 88(5), 879-903.

34. Roussel P, Durrieu F, Campoy E et Akremi A.E (2002), Méthodes d'équations structurelles : Recherche et Applications en Gestion, Paris, Economica.

35. Royer I et Zarlowski P (2003), Méthodes de recherche en management,
Chapitre 8, pp. 188-223, in Thiétart, R.A., Dunod.

36. Schwab, D. P. (1980), Construct validity in organizational behavior. In B.W. Straw, \& L. L.Cummings (Eds.), Research in organizational behavior, Vol. 2. (pp. 243)Greenwich, CT: JAI Press.

37. Shimp T et Kavas A (1984), The Theory of Reasoned Action Applied to Coupon Usage, Journal of Consumer Research, Vol 11, issue 4, pp 795-809.

38. Volle P (1996), Impact du marketing promotionnel des distributeurs sur le choix du point de vente et rôle modérateur de variables individuelles, Thèse de Doctorat en Sciences de Gestion, Paris IX Dauphine. 